\title{
When Mayors Matter: Estimating the Impact of Mayoral Partisanship on City Policy
}

\author{
Elisabeth R. Gerber University of Michigan \\ Daniel J. Hopkins Georgetown University
}

\begin{abstract}
U.S. cities are limited in their ability to set policy. Can these constraints mute the impact of mayors' partisanship on policy outcomes? We hypothesize that mayoral partisanship will more strongly affect outcomes in policy areas where there is less shared authority between local, state, and federal governments. To test this hypothesis, we create a novel dataset combining U.S. mayoral election returns from 1990 to 2006 with city fiscal data. Using regression discontinuity design, we find that cities that elect a Democratic mayor spend a smaller share of their budget on public safety, a policy area where local discretion is high, than otherwise similar cities that elect a Republican or an Independent. We find no differences on tax policy, social policy, and other areas that are characterized by significant overlapping authority. These results suggest that models of national policymaking are only partially applicable to U.S. cities. They also have implications for political accountability: mayors may not be able to influence the full range of policies that are nominally local responsibilities.
\end{abstract}

A

merica's large cities differ widely, but a contemporary observer could sum up their shared fiscal situations in one word: austerity. The current economic recession is taking a heavy toll on already stretched city budgets, leaving many cities struggling to meet their service obligations in the wake of sharply declining revenues. City revenues that derive largely from property taxes are tumbling with the collapse of the housing market and waves of foreclosures (Hoene and Pagano 2009; Pagano and Hoene 2008). State transfers to cities are plummeting as state governments deal with their own revenue shortfalls (Eaton 2009). At the same time, demand for social services is growing as unemployment numbers rise (Hubert 2008). Local officials face a great deal of pressure to balance their budgets, continue to provide high-quality services, and avoid layoffs of public employees.

In this article, we investigate whether mayors' political preferences are likely to shape their responses to these (and other) fiscal pressures. Do Democratic mayors differ in their fiscal policies from Republicans or Independents? Does partisanship lead cities to adopt significantly different fiscal policies? Political science research is far from clear on the matter, offering two opposing perspectives. Scholarship on U.S. national politics has demonstrated the dominance of partisan considerations in shaping policy outcomes. This body of research has shown repeatedly that the two major parties have distinct electoral coalitions and governing philosophies that lead to quite different policy outcomes, especially on issues of taxing and spending (Aldrich 1995; Bartels 2008; Gerring 1998; Hacker and Pierson 2005; McCarty, Poole, and Rosenthal 2006; Poole and Rosenthal 1997). In national politics, partisanship appears to be a kind of theoretical "skeleton key" that is commonly invoked to explain both voter decision-making and elite policy choices (Goren 2005; Green et al. 2002; McCarty, Poole, and Rosenthal 2006). Moreover, party polarization, at least among elites, has grown in recent years (Fiorina, Abrams, and Pope 2006; McCarty, Poole, and Rosenthal 2006).

Elisabeth R. Gerber is a Professor in the Gerald R. Ford School of Public Policy and a Research Associate in the Center for Political Studies, Institute for Social Research, University of Michigan, 5228 Weill Hall, 735 S. State St., Ann Arbor, MI 48109-3091 (ergerber@umich.edu). Daniel J. Hopkins is an Assistant Professor in Government, Georgetown University, ICC, 37th and O Streets NW, Washington, DC 20057 (dh335@georgetown.edu).

Previous versions of this research were presented at the 2009 annual meetings of the Midwest and American Political Science Associations, as well as the 2009 Summer Meeting of the Society for Political Methodology and the Georgetown University Political Economy Seminar. The authors wish to thank Fernando Ferreira, Joseph Gyourko, and Justin Phillips for sharing data as well as Michael Bailey, Christopher Berry, Devin Caughey, Donald P. Green, Jonathan M. Ladd, Gabriel Lenz, Marc Meredith, Anirudh Ruhil, Jessica Trounstine, and Carol Weissert for comments or other assistance. The authors thank MIT for institutional support. Katherine T. McCabe contributed with thoughtful and tireless research assistance. We are grateful as well to AJPS editor Rick Wilson and the anonymous reviewers.

American Journal of Political Science, Vol. 55, No. 2, April 2011, Pp. 326-339

(C)2011, Midwest Political Science Association

DOI: $10.1111 /$ j.1540-5907.2010.00499.x 
By contrast, scholars of urban politics have consistently emphasized the economic, political, and legal constraints facing local policymakers (Leigh 2007; Nivola 2002; Peterson 1981, 1995; Rae 2003; Self 2003; Tiebout 1956). Indeed, given the overwhelming emphasis on constraints in past studies of urban politics, it is unclear what policy influence mayors or other local political officials can have even under normal conditions. By extension, it is also unclear that mayors of one political party are able to govern in distinctive ways. The old adage that there is no Republican or Democratic way to collect trash, attributed to New York's Mayor LaGuardia, appears quite compatible with the reigning theories of urban politics.

We thus have two theoretical approaches, each dominant within its domain, which make very different predictions about the impact of partisanship on local policy. Given the strength of partisanship in national politics, and given that the same two major parties compete in many local elections, we might expect partisan control of city government to systematically influence local policy. Democratic mayors might pursue increased taxes and expanded services, and Republican mayors might pursue tax cuts and service reductions, just as their national counterparts do. Alternately, if the various constraints on urban policymakers are binding, the impact of mayoral partisanship might prove negligible, as cities act based on fiscal and economic conditions rather than political ones. This article tests these competing possibilities, focusing on the nature and extent of constraints faced by local policymakers in various areas of urban fiscal policy. In doing so, it evaluates the applicability of prominent theoretical explanations of national-level politics to local policymaking.

Foreshadowing our empirical results, we find that mayors' partisanship is an important determinant of fiscal outcomes in some policy areas where local decision makers are less constrained by political actors at other levels of the U.S. federal system. Yet it is negligible in areas where federal and state actors exert more authority. In other words, models of the effects of partisanship on policymaking apply to some areas of local politics but not to others. These conditional results should encourage scholars of local politics to carefully consider the applicability of models of national politics. They should also prompt scholars of national politics to consider when and how national actors exert influence over other actors within the federal system.

We proceed as follows. The next section integrates theories of political partisanship and theories of urban political constraint. Past research has pointed to both formal constraints on the local policymaking process, such as legal restrictions on what local governments can do, and informal constraints, such as the political and economic environment in which cities operate. While cities may indeed be constrained, these constraints are neither insurmountable nor universal; we expect the constraints cities face to vary across policy areas. We focus in particular on the constraints imposed by the division of authority within the U.S. federal system. In policy areas where cities share authority with federal and state government actors, such as housing and transportation, we hypothesize that a mayor's partisanship will have a limited influence on policy. In areas where there is less shared authority, such as policing and public safety, we hypothesize that a mayor's partisanship will more strongly influence policy.

Empirically, we test this hypothesis using a novel dataset of 134 mayoral elections in large U.S. cities from 1990 to $2006 .{ }^{1}$ In the third section, we describe our data set, which includes cities with partisan elections as well as those with nonpartisan elections where the two leading candidates were known to be from different parties. Together with data from the U.S. Census of Governments and the Annual Survey of Governments databases, these new data allow us to estimate the influence of a mayor's partisanship on a wide range of tax and spending policies, as detailed below. To confront concerns about the potential endogeneity of partisanship, we use regression discontinuity design (RDD), an increasingly common statistical technique that can recover the causal impact of partisanship by comparing outcomes in cities that witness a narrow victory by a mayoral candidate of one political party to outcomes in similar cities where there was a narrow victory by a candidate of a different party (Ferreira and Gyourko 2009; Green et al. 2009; Imbens and Lemieux 2007; Lee, Moretti, and Butler 2004; Leigh 2007; Trounstine forthcoming).

The fourth section reports our empirical results. Consistent with the observation that constraints vary across policy areas, we find that mayoral partisanship influences spending on some policies but not others. Those cities that elect a Democratic mayor by a slim margin can expect the share of their budget devoted to police spending to be approximately 2 percentage points lower three years later, and their fire spending to be approximately 1 percentage point lower, than if they had elected a Republican mayor. ${ }^{2}$ However, other spending areas and city revenue streams, over which cities have only limited discretion, show no strong partisan influence. The article's

\footnotetext{
${ }^{1}$ The data set is available at http://dvn.iq.harvard.edu/ $\mathrm{dvn} / \mathrm{dv} / \mathrm{DJH}$ Hopkins. Other supporting information is available at www.danhopkins.org.

${ }^{2}$ The comparison of Democratic victories to Republican victories is arbitrary, as all estimates provide the impact of one party's victory relative to a victory by the other party.
} 
empirical results prove highly robust: they do not appear in placebo tests described below, but they do persist irrespective of the independent variables and functional forms employed, the number of elections included in the data set, and other analysis decisions.

These findings help us understand the constraints that bind city policy. They illustrate that those constraints allow for mayoral influence in certain policy areas while severely limiting the impact of partisanship and partisan polarization on other local policy outcomes. When partisan mayors are less constrained, they can act on their own preferences and/or be responsive to their partisan constituents in ways that are not available when they are more severely constrained. Contemporary work on national politics would suggest that partisanship is a powerful influence in American politics. The results presented here suggest a more nuanced story, at least for local governments. We elaborate these and other implications in the final section.

\section{Theorizing Partisanship's Local Impacts}

This section builds upon the large literatures on partisanship, urban politics, and public policy to generate hypotheses about the impact of local government partisanship on policy outcomes. Developed to explain political processes at two different levels of government, these literatures generate contradictory expectations about the impact of local partisanship. This section seeks to integrate those literatures to develop hypotheses about when partisanship is likely to influence local policy outcomes. It suggests that we should expect the degree of constraint on local partisan officials, and hence their ability to shape policy outcomes, to systematically vary by policy area.

\section{Partisanship and Local Government}

We begin with the literature on partisanship at the national level. The strong and robust conclusion of this research is that partisan differences are key factors in explaining the policy preferences of citizens and decision makers. At the level of individual citizens, partisan identification is a more stable predictor of vote choice than demographic characteristics or ideology (Campbell et al. 1960; Goren 2005; Green, Palmquist, and Schickler 2002) and is thought to be a central heuristic through which voters make decisions (Popkin 1994; Schaffner, Streb, and Wright 2001). The partisanship of elected officials also proves an unparalleled predictor of changes in public policy at the federal (Bartels 2008; Clinton, Jackman, and Rivers 2004; Hacker and Pierson 2005; Krehbiel 1998; McCarty, Poole, and Rosenthal 2006; Poole and Rosenthal 1997) and state (Barrilleaux, Holbrook, and Langer 2002; Erikson, Wright, and McIver 1993; Wright and Schaffner 2002) levels. The fact that party labels are consistently associated with policy positions allows voters to differentiate candidates based on their likely actions in office.

Yet despite the sustained attention to partisan identification, there have been few studies of its influence across the levels of the U.S. federal system (but see Ferriera and Gyourko 2009; Niemi, Wright, and Powell 1987; Schleicher 2007). Green, Palmquist, and Schickler (2002, 44) argue that partisan identification is a social identity and that American voters do not have separate partisan identifications at the local, state, and national levels. If this is true, then we might expect party labels in local politics to function largely as they do in national politics. Democratic mayoral candidates should be associated with increased social spending and higher, more progressive taxation. Republicans should be associated with increased spending on "defense-like" policies such as public safety, and lower, more regressive taxation.

Alternately, it is plausible that national partisan labels do not influence local elections (see also Leigh 2007), which may instead be decided using alternate cues such as a candidate's race, endorsements, or personal characteristics. Certainly, the presence of Republican mayors in overwhelmingly Democratic cities-consider Rudolph Giuliani in New York or Richard Riordan in Los Angelesprovides a hint that partisanship may function differently at the local level. But exactly how partisanship influences local elections and local governance is not well understood.

Ferreira and Gyourko (2009) provide a valuable starting place for answering these questions. Their research analyzes data for 413 cities from 1950 to 2005 to estimate the impact of partisanship on local public finances. It finds no strong relationships, and attributes the null findings to the relative homogeneity of preferences within a given city. Their research draws on Tiebout (1956) by arguing that individuals sort into localities based on their preferences, meaning that there is insufficient preference diversity to generate party competition on policy grounds in a given city. The resulting prediction: mayoral partisanship will have consistently null effects across all areas of city taxes and revenues.

\section{Cities' Constraints}

We develop a different hypothesis about fiscal policy outcomes by drawing on research on urban constraints. The U.S. federal system is characterized by high degrees of 
overlapping authority between the federal, state, and local governments (Grodzins 2000). Unlike the U.S. states, American cities have no independent constitutional status; they are creatures of the states and derive their powers and authority wholly from state constitutions and statutes (Briffault 1990). ${ }^{3}$ In addition, there are numerous statelevel statutory or constitutional constraints on specific local policies, particularly in the area of taxation (Ladd and Yinger 1989, chap. 6). ${ }^{4}$ Beyond these structural constraints, there are a great many areas in which responsibility over policy is shared between levels of government (Berman 2003; Craw 2006; Nivola 2002; Peterson 1995). Examples include direct federal and state mandates on local governments (as in the areas of national security and education) and federal-state-local partnerships (as in surface transportation policy). Federal and state governments also exert control over local policy by providing money (e.g., block grants for policies such as housing, community development, and welfare). Apart from these legal, institutional, and financial constraints, cities also face well-known fiscal limitations stemming from economic competition (Bailey and Rom 2004; Ladd and Yinger 1989; Peterson 1981; Rae 2003). Given this litany of constraints, it is unsurprising that past work commonly concludes that political factors have little influence on state (Leigh 2007) and local (Craw 2006; Morgan and Watson 1995; Peterson 1981; Ruhil 2003; but see Wolman, Strate, and Melchior 1996) policy outputs.

By contrast, some areas of public policy are viewed as the domain of local governments. For example, in the area of policing, federal involvement since the 1990s has been largely limited to specific program areas such as community policing (Roth and Ryan 2000) and, recently, counterterrorism (Richman 2006). Local agencies make most consequential decisions about how much to spend and how to deploy their resources across staffing, equipment, investigations, and facilities outside the control of state or federal mandates (Geller and Morris 1992; Peterson 1981). Cities also provide most of the financing for their public safety programs out of own-source, general

\footnotetext{
${ }^{3}$ Legal scholarship differentiates between two types of state-local legal relationships. In home rule states, cities and other local governments have relatively high degrees of autonomy in specific areas such as their structural, functional, fiscal, and personnel powers, whereas in Dillon's rule states, local governments are limited to the functions and powers explicitly granted to them by the state.

${ }^{4}$ For more on the limitations on local taxation, see especially Fisher (2003), which details the narrowing of fiscal differences across states and localities in the last decades of the twentieth century. On the fiscal impact of tax and expenditure limitations-including California's Proposition 13, Michigan's Headlee Amendment, and Massachusetts' Proposition $21 / 2$-see Mullins (2003) and Wallin (2004).
}

fund revenues. For the cities in our data set, state and federal intergovernmental revenues account for $81 \%$ of their total spending on housing, 33\% of their total spending on roads, and $27 \%$ of their total spending on health and hospitals. But the comparable shares for policing and fire are so small that they are not reported. ${ }^{5}$ And even if every dollar of miscellaneous intergovernmental revenue went to fire and policing, the comparable share would be no larger than $21 \%$. In all likelihood, the true figure is considerably smaller.

Building on the literatures emphasizing cities' constrained authority, we contend that partisanship will play a larger role in policy areas where there is less shared authority between local, state, and federal governments, and a smaller role where shared authority is high. We focus on the partisanship of a city's mayor, since mayors (especially in large cities) typically have significant agenda control as well as budget-drafting authority (ICMA 2001). Mayors are clearly not the only actors who participate in fiscal policymaking, but they are especially influential. They are also more easily observable.

We begin with the assumption that a mayor's partisanship is a strong determinant of his or her personal fiscal policy preferences and that the mapping between a mayor's partisanship and policy preferences will have some correspondence to the mapping that exists at the national level. Political parties are coalitions of officeholders that coordinate across levels of government (Aldrich 1995), a fact which is likely to induce some stability in partisans' policy preferences (Gerring 1998). Our approach is agnostic with respect to how mayors obtain their partisan identification and policy preferences. Nor do we assume that partisans' policy preferences are necessarily identical at the national and local levels, but simply that stances on a given issue are correlated across levels. Since Republican officials at the national level tend to be more concerned about reducing crime or cutting taxes, while Democratic national officials are more concerned about expanding social programs (Edsall 1991; Jacobson 1990; Petrocik 1996), we expect similar tendencies to hold at the local level. Regardless of the origins of these preferences, their implication for our theory is simple: in the absence of constraints, mayors from different parties would prefer to enact different policies, and those policies correspond to national partisan cleavages.

Yet we expect the presence of constraints on local authority to moderate the ability of mayors to act upon these preferences as they shape, promote, enact, and

\footnotetext{
${ }^{5}$ Many federal and state public safety programs involve grants to local police departments for specific activities (Richman 2006); these funds are not separately identified in the fiscal data we employ.
} 
implement local policies. This leads us to hypothesize that the influence of partisanship on local policy will be stronger in areas like public safety where overlapping authority is less, and weaker in areas like taxation and social policy where overlapping authority is greater. We test this hypothesis against two alternative hypotheses. Drawing from studies at the national level, the first alternative contends that partisanship is an important determinant of outcomes in most local policy areas. The second, effectively a null hypothesis, holds that partisanship is not an important determinant of local outcomes and is consistent with the perspective offered by Tiebout (1956) and Ferreira and Gyourko (2009).

\section{Methods and Data}

This section outlines our empirical strategy and describes the data sets we employ. The conceptual approach described above implies a simple statistical model in which the mayor's partisanship affects patterns of revenues and expenditures, and constraints on a city's policy authority dampen or enhance this relationship. However, mayoral partisanship is not randomly assigned to cities, introducing the possibility of endogeneity. Cities that tend to elect Democratic administrations are likely to be quite different from cities that typically elect Republicans in both observable and unobservable ways. In a statistical model, we can (at least in theory) control for the observable differences with the inclusion of covariates. But by definition, we cannot control for the unobserved differences, leading to the possibility that these factors will bias our estimates.

Our empirical approach seeks to isolate the factors that influence the degree of discretion over policy while addressing the complicating factors of endogeneity and data availability. Specifically, we employ a regression discontinuity design (RDD), an increasingly common approach to making causal inferences from observational data (Ferreira and Gyourko 2009; Folke 2009; Gerber, Kessler, and Meredith forthcoming; Green et al. 2009; Hahn, Todd, and Van der Klauuw 2001; Imbens and Lemieux 2007; Leigh 2007; Meredith 2009; Mullainathan and Washington 2009; Trounstine 2009; Warren 2009). One recent review finds that RDD approaches consistently recover experimental benchmarks (Cook, Shaddish, and Wong 2005), a strong assertion of their methodological value. ${ }^{6}$

\footnotetext{
${ }^{6}$ Minimally, RDD should provide a lower bound on the impact of partisanship since candidates who narrowly win are likely to moderate their policy proposals in anticipation of the next election.
}

This article follows Lee, Moretti, and Butler (2004) and Ferreira and Gyourko (2009) by treating election results as continuous variables measuring a city's propensity to elect a Democrat. However, as Lee, Moretti, and Butler (2004) point out, there is a critical discontinuity in election outcomes: Democrats who win $49.9 \%$ of the two-candidate vote lose the election, while Democrats who receive $50.1 \%$ of the two-candidate vote win. This article uses close elections like these to estimate the influence of a narrow Democratic victory on subsequent policy outcomes. In other words, the RD design allows us to compare cities that are quite similar in their probability of electing a Democrat but that differ in the actual partisanship of their mayor. By making the assumption that policy outputs are a smooth function of the propensity to elect a Democrat, we can exploit this discontinuity to recover the local average treatment effect, where the "treatment" is the election of a Democratic mayor. The fact that this is a "local" average treatment effect indicates that we are not estimating the overall impact of electing a Democrat, but instead the impact of a razor-tight Democratic victory. As compared to other observational research, this regression discontinuity approach markedly reduces the threat of omitted variables. To bias RDD inferences, any omitted variable would have to be unevenly distributed at the point of the discontinuity (Green et al. 2009; Imbens and Lemieux 2007). There is no reason to expect that cities where Democrats barely win have, for example, markedly different crime rates, economic patterns, or political institutions than cities where they barely lose. Still, the richness of available covariates allows us to confirm these assumptions for many observed variables. The covariates also enable us to rule out the possibility that our results are driven by strategic behavior or election fraud in elections near the discontinuity (see also Caughey and Sekhon 2010). Importantly, our RDD allows us to test our hypotheses about how the presence of constraints moderates the relationship between partisanship and outcomes. ${ }^{7}$

\section{Data Compilation}

Testing our hypotheses requires a data set that combines information on local government policy outputs,

Perhaps for that reason, this study is among the first to detect policy impacts using this method (see also Leigh 2007 and Warren 2009).

${ }^{7}$ An alternative approach would compare changes in city policies after a partisan transition. However, we observe only 21 cases of known party transitions, severely limiting the power of such tests. In addition, focusing on transitions does not address the endogeneity issue and hence allow the strong causal inferences supported by RDD. 
mayoral election returns, policy characteristics, and features of the local political and policy environment. City elections (and mayoral elections in particular) occur at different times under different rules, and no comprehensive record of their results currently exists. Some cities elect mayors every two years, some do so every four years, and some forego direct mayoral elections entirely. Testing for the influence of mayoral partisanship is harder still, since the majority of U.S. cities use formally nonpartisan elections. We thus collected data on a city-bycity basis, using information from election commissions, archived newspaper articles, official city websites, the International County/City Management Association, the National Conference of State Legislatures, the 1987 Census of Governments, and other sources. The resulting data set is, to our knowledge, the most comprehensive data set on direct mayoral elections for large U.S. cities from 1990 onward. $^{8}$

The target universe is the 130 largest U.S. cities as identified by the U.S. Census Bureau in 2007. The $130^{\text {th }}$ city is Brownsville, Texas, with a 2007 population of just over 170,000 people. For each large-city mayoral election beginning in 1990, we sought information on when the election occurred, the votes received by the top four candidates, the candidates' party affiliations, and their racial and ethnic backgrounds. We also recorded whether the city's elections were formally partisan or nonpartisan, whether the winner was an incumbent, and whether city hall changed parties after the election. Since some nonpartisan elections allow candidates to indicate their party affiliation on the ballot, we recorded this information as well. ${ }^{9}$ While only $14 \%$ of the elections in our sample took

\footnotetext{
${ }^{8}$ As compared to the data set employed by Ferriera and Gyourko (2009), this data set has advantages and disadvantages. Ferreira and Gyourko's sample extends back to 1950, and its sampling strategy includes many smaller U.S. cities. By contrast, the data employed here cover a shorter time frame and consider only the largest U.S. cities. Yet the data used here are based on publicly available records rather than surveys of local government officials. As a result, these data are not subject to concerns about unreturned surveys, and the threats of measurement error and response bias are much reduced. Moreover, if the newspapers we rely on fail to indicate a candidate's partisanship in a single article, it is unlikely that partisanship was central to the mayoral election. Our sample thus selects for cities where partisanship has more potential to structure elections and shape policy. An additional advantage of our data set is the richness of the available covariates. Given the sample size, we are able to collect data on institutional features that have not previously been measured, such as the use of party labels on the ballot.

${ }^{9}$ These elections are deemed "nonpartisan" because the political parties do not formally nominate candidates for the general election.
}

place in cities with formally partisan elections, $30 \%$ took place in cities where party labels can appear on the ballot. From the Census of Governments, we learn whether the city has a mayor-council or council-manager system as well as the size of the city council and the districting scheme. Past research has found that those institutional factors can influence politics and policy (e.g., Baqir 2002; Fuchs 1992; Welch 1990), and they may well moderate the impact of mayoral partisanship. Where cities elect mayors through a run-off system, we included the results of the final election. Of the target universe, we recovered some information for 522 mayoral elections taking place in 120 cities.

However, not all of these elections are equally useful in estimating the impact of partisan composition on local fiscal policy. In 302 cases, we were not able to obtain the party affiliation of the second-place candidate. In many of these cases, such information simply does not exist, as many candidates for local office do not declare their partisanship. This leaves us with 220 elections contested in 81 cities. Of this sample, we must also drop cases where both candidates were from the same party, leaving us with 134 elections from 59 cities. This sample is by no means representative of U.S. cities as a whole, or even of large U.S. cities. But our quantity of interest-the impact of electing a Democrat over a candidate from another party-is identified only for this subsample.

To evaluate the characteristics of this limited sample, we compare it to the original universe of elections using a logistic regression where the dependent variable is inclusion in our subsample. The cities in our sample have significantly larger populations, lower population growth, higher median household incomes, faster median household income growth, larger poor populations, and fewer immigrants. Not surprisingly, the included cities are also more likely to have partisan elections. The black populations of cities in the sample are not notably different from the larger population of big cities, and conditional on the factors above, included cities are no more likely to be in a particular region of the country. Of the races that made it into our sample, 108 were cases where a Democrat ran against a Republican, while the remaining 26 saw Democrats running against independents or minor-party candidates. For each election in our sample, we calculate the percentage of the votes for the top two candidates that was received by the Democrat. On average, the Democrat won $57 \%$ of the vote. However, there are 44 cases where the Democrat lost and another 18 cases where the Democrat won with less than $55 \%$ of the vote. Table SI1 provides descriptive statistics. 


\section{Measuring Local Policy}

Our measures of local fiscal policy are drawn from the U.S. Census Bureau's Annual Survey of Governments and its Census of Governments, which provide detailed revenue, expenditure, and employment data for U.S. local governments from 1970 to 2006. By merging these data with the mayoral election data described above, we are able to observe a wide range of policies before and after the mayoral election in question.

On the expenditure side, we focus on direct expenditures in key spending categories, including policing, fire, housing, healthcare, roads, parks, natural resources, libraries, sanitation, administration, and code enforcement. For each category and each year, we compute the share of the total direct expenditures devoted to that policy area. ${ }^{10}$ Like past researchers, we use such spending shares to measure changing policy priorities (e.g., Alesina, Baqir, and Easterly 1999; Hajnal and Trounstine 2005; Jacoby and Schneider 2001; Peterson 1981; Wolman, Strate, and Melchior 1996, 213). ${ }^{11}$

We also consider a variety of measures of local revenue policies, including total taxes per capita, logged total tax collections, the share of local taxes that come from the sales tax, the share of local taxes that come from the property tax, and local taxes as a share of total local revenues. Together, these measures allow us to observe changes in the source and size of revenue streams. For instance, it could be that Republican mayors prefer more targeted revenue sources and so increase users' fees while shifting away from broad-based taxes. By analyzing the share of local revenues that come from taxes, we will detect such shifts. Coarsely, we will also be able to identify shifts in more progressive revenues sources (such as property taxes) as well as more regressive revenues sources (such as sales taxes).

Finally, we consider a number of policy outcomes that deal less with how cities allocate their budget dollars across policy areas, and more with how dollars are allocated to spending items within a given policy area. Specifically, we consider changes in the number of police department employees, the share of public employees who are in the police department, and changes in po-

\footnotetext{
${ }^{10}$ Modeling changes in spending shares allows us to account for the vast differences in the services cities provide, since we are modeling differences from each city's baseline spending level.

${ }^{11}$ We exclude capital and construction expenditures as such expenditures commonly reflect decisions made in previous years. We would not, for example, want to consider an increased construction budget under one mayor to be the result of her election if such increases were actually budgeted by her predecessor. Studying direct current expenditures allows us to capture that portion of each city's budget that is most directly shaped by the current mayor.
}

lice employee pay as a share of total payrolls. We include these additional outcomes to investigate the possibility that even if Democratic and Republican mayors are constrained in the amounts they spend on various policy areas, they may still differ in their approaches to public employment and personnel policies. ${ }^{12}$

Table SI2 describes the numerous measures used to create the dependent variables, with spending categories in the top section, revenues in the middle section, and employment in the bottom section. As the first column makes clear, in the average year, policing receives more direct current expenditures than any other spending category, followed by roads and fire protection. The final column reports the ratio of policy-specific intergovernmental revenues (as reported in the Annual Survey of Governments) to direct spending in that category. While federal, state, and local governments have numerous mechanisms for controlling local policy, including those discussed above, we expect money-and the conditions attached to grants and intergovernmental transfers - to exert an especially powerful constraint on the ability of mayors to shape local policy in a partisan direction.

\section{Results}

In this section, we report the results of our empirical analyses. We first establish our baseline estimates of the relationship between local partisanship and city fiscal policy by focusing on an area of spending where one important form of constraint-intergovernmental transfers-is low and hence where we expect a strong partisan impact. That area is public safety. We then test our core hypothesis by comparing this estimated relationship across several policy areas that vary in their degree of overlapping authority. This section and the Supplemental Information provide additional robustness tests for the key findings, showing that they are not driven by the handling of missing covariates, outliers, observations far from the discontinuity, or many potentially omitted variables.

\section{Modeling Spending on Public Safety}

Cities vary in their functional responsibilities, a fact which poses significant challenges for cross-city comparisons (Peterson 1981). In part, we confront this concern by

\footnotetext{
${ }^{12}$ Large literatures investigate local government personnel policies in general, and police department staffing strategies in particular. These studies consider such factors as collective bargaining (Methe and Perry 1980), asset specificity and transactions costs (Brown and Potoski 2003), and management science (Green and Kolesar 2004). Our review of these literatures failed to uncover any that examine partisan political influences.
} 
focusing on core city functions such as policing, fire protection, libraries, parks, and roads, which are common across most large cities. We also specify the dependent variables in our analyses as changes in spending shares, revenue, and employment outcomes in the three years after a mayoral election, a choice which means that our analyses will not be confounded by baseline differences in cities' functional responsibilities. For all analyses, the baseline year is the fiscal year during which the election took place. The changes are continuous variables and can reasonably be modeled using Ordinary Least Squares (OLS).

When considering regression discontinuities, the critical independent variables are the indicator for the discontinuity-in this case, whether the Democrat won the election-and the underlying continuous measure of support for the Democratic candidate. This continuous measure is known in RDD research as the "forcing" variable; it is operationalized as the winner's share of the votes received by the top two candidates. Ideally, we would focus only on observations that are very close to the discontinuity, reducing model dependence (Green et al. 2009; Imbens and Lemieux 2007, 616). But given the relatively small sample size, we need to rely to some extent on observations that are more distant from the discontinuity. Our models thus need to capture the underlying functional relationship between partisanship and fiscal policies across a wide range of election outcomes. To do so, we include not only a measure of the percent of the electorate supporting the Democrat, but also squared and cubed measures of Democratic support to account for this potentially complex relationship. ${ }^{13}$ Following past procedure (e.g., Lee, Moretti, and Butler 2004), we also interact these measures with the binary indicator for Democratic victories, which allows the various functions of the percent Democratic to vary across the discontinuity. This approach reduces the chance that our results stem from mis-specifying the relationship between Democratic support and policy choices.

Table 1 presents an initial model of the change in the share of spending devoted to police. In part, we begin with police spending because it is the largest spending category for the cities in our sample, accounting for $11 \%$ of all direct operating expenditures on average. It is also a theoretically informative starting place. It is a policy area characterized by relatively low levels of overlapping authority, so if partisanship can influence any spending area, it should influence policing. The model uses multiple imputation to prevent the deletion of eight observations

\footnotetext{
${ }^{13}$ The results are robust to the inclusion of quartic terms or the removal of cubed terms as well.
}

with missing values for at least one variable (King et al. 2001; Schafer 1997). The standard errors are clustered by city (Wooldridge 2003).

In theory, the various functions of the Democratic candidate's vote share are the only covariates necessary to ensure an unbiased estimate of the impact of a Democratic mayor in our RD design. Still, as with randomized experiments, the use of pretreatment covariates can improve efficiency and remove covariate imbalances that occur by chance (Green 2009). Our core analyses thus condition on a handful of covariates, although the robustness checks in the Supplemental Information show that our results do not depend on these specification choices. In 26 of these elections, the opponent is an independent rather than a Republican, so we condition on an indicator variable for those cases. City fiscal years most commonly end in June, but to account for heterogeneity across cities, we condition on an additional indicator variable for the $25 \%$ of cities in our sample whose fiscal years end in December. In our initial modeling, we also condition on the city's 1990 population, its percent black, its logged median household income, and its baseline intergovernmental revenue per capita. In interpreting these results, it is important to keep in mind that the indicator variable for a Democratic victory is interacted with the three continuous measures of Democratic support. ${ }^{14}$

The first model indicates that all else equal, a city where the Democrat just wins the mayoralty should expect its spending on police to drop by 2.3 percentage points three fiscal years later. This result is statistically significant, with a $95 \%$ confidence interval that runs from 0.5 percentage points to 4.0 percentage points. It is substantively large as well, as it reflects a spending shift of 1.2 standard deviations in terms of the dependent variable. Figure 1 illustrates the regression discontinuity design and reports our empirical estimate graphically. The black dots represent the observed change in police spending (on the y-axis) as a function of the percentage of the vote received by the Democrat (on the $\mathrm{x}$-axis). The open circles show our OLS model's prediction for each city election and illustrate the magnitude of the estimated discontinuity. The figure makes it clear that there is a sharp discontinuity - a relative decline in police spendingwhen Democratic mayors narrowly win. The figure also illustrates that the difference is driven more by the average increase in anticrime spending under Republicans (1.8 percentage points) than by the average decrease under Democrats $(-0.4$ percentage points). The results are

\footnotetext{
${ }^{14}$ Also, the measure of Democratic support is recentered by subtracting 0.50 to facilitate the interpretation of the coefficients.
} 
TABLE 1 OLS Estimates, DV = Change in the Share of City Spending on Police, 134 City Elections

\begin{tabular}{lrrrc}
\hline & \multicolumn{1}{c}{$\beta$} & \multicolumn{1}{c}{ SE } & \multicolumn{1}{c}{$\beta$} & SE \\
\hline Intercept & 0.008 & 0.114 & 0.017 & 0.008 \\
Democrat Wins & -0.023 & 0.009 & -0.020 & 0.009 \\
Pct Democrat & 0.299 & 0.275 & 0.278 & 0.269 \\
Pct Democrat Squared & 2.299 & 2.658 & 2.189 & 2.625 \\
Pct Democrat Cubed & 5.114 & 6.262 & 4.956 & 6.182 \\
Independent Loses & -0.001 & 0.004 & & \\
December FY & -0.004 & 0.004 & & \\
Logged 1990 Population & -0.005 & 0.002 & & \\
Pct Black 1990 & -0.011 & 0.011 & & \\
Logged Median Income 1990 & 0.008 & 0.011 & & \\
Intergovernmental Revenue per Capita & 0.001 & 0.002 & & \\
Democrat wins x Pct. Democrat & -0.313 & 0.319 & -0.302 & \\
Democrat wins x Pct. Democrat & -1.794 & 2.683 & -1.731 & 2.645 \\
$\quad$ Squared & & & & \\
Democrat wins x Pct. Democrat & -6.152 & 6.388 & -5.889 & \\
$\quad$ Cubed & & & & \\
\hline
\end{tabular}

FIGURE 1 RDD Model and Results

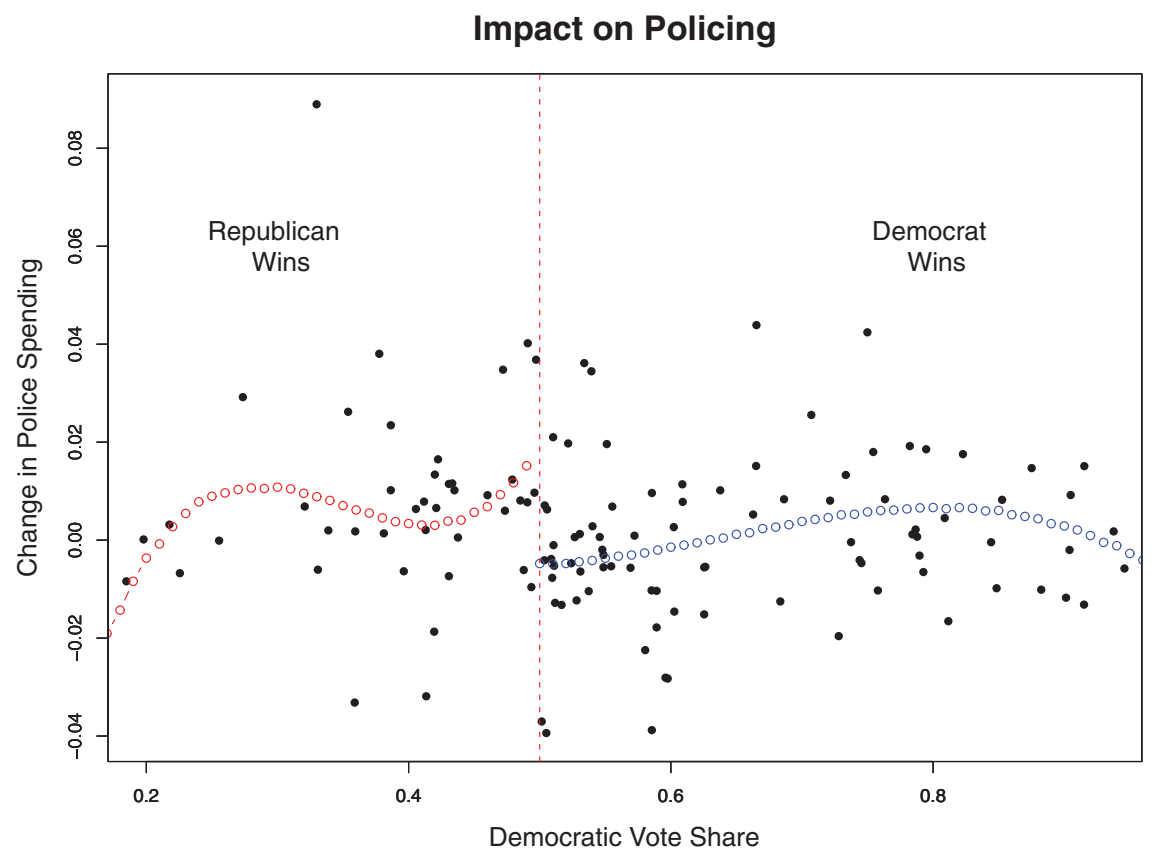

Note: Black dots depict the bivariate relationship between each city's Democratic support and the subsequent three-year change in police dpending. Open dots depict the predicted change from the baseline RDD model.

not sensitive to the inclusion or exclusion of other independent variables, as the second model in Table 1 shows.

Table SI3 reports comparable results for the change in the share of spending devoted to fire protection, the other major category of public safety. It, too, consumes a significant share of local revenues, and is subject to relatively few federal and state mandates. These results demonstrate a similar effect of a narrow Democratic victory: in cities 


\section{FIGURE 2 OLS Estimates, Effect of a Democratic Victory on Outcomes}

\section{Effect of Democratic Win}

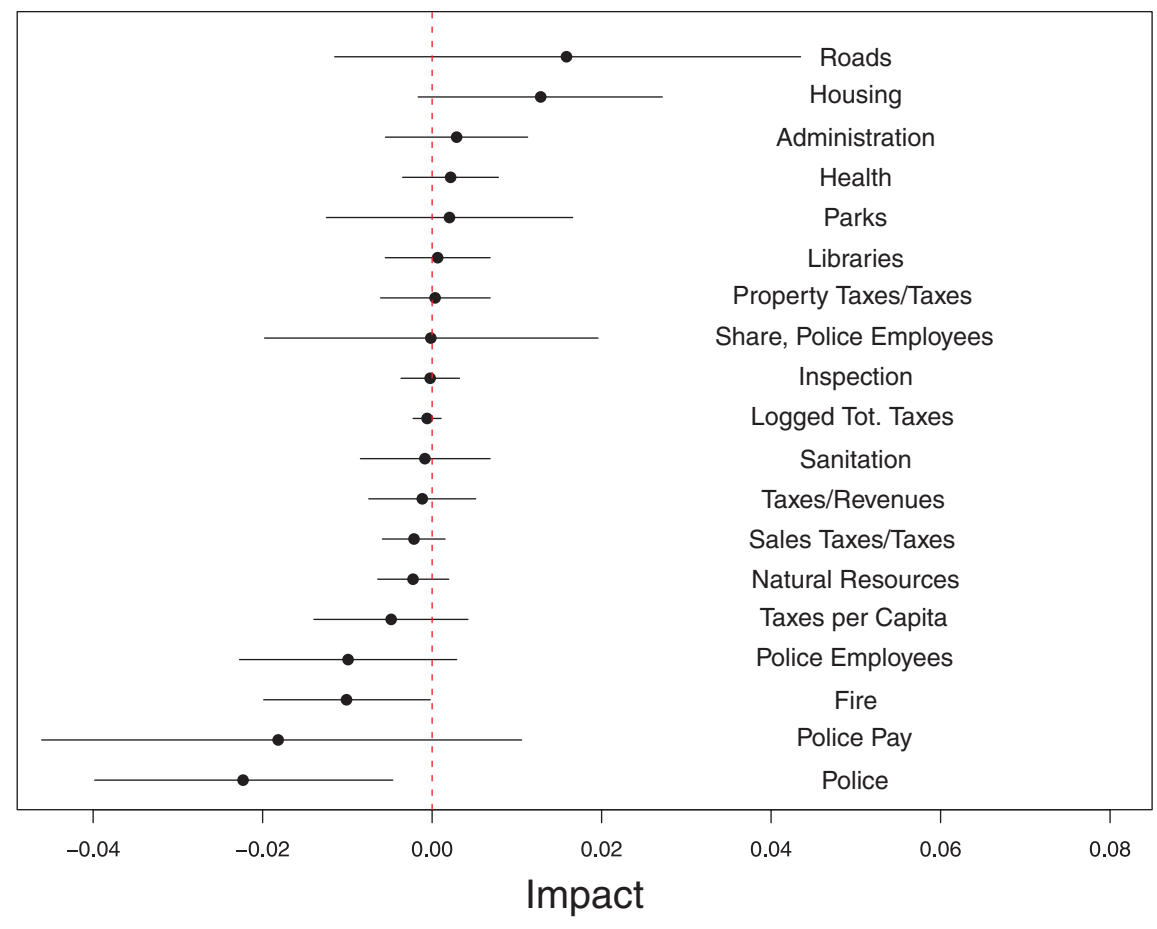

Note: Conditional on covariates in Table 1, estimated on multiply imputed data sets with standard errors clustered by city.

where a Democrat barely wins, we can expect a 1.0 percentage point drop in spending on fire protection, with a $95 \%$ confidence interval from 0.04 percentage points to 2.0 percentage points. Again, this impact appears to be driven more by increases under Republicans than decreases under Democrats.

\section{Modeling Changes in Spending Shares}

We then apply the same statistical methods, including multiple imputation and standard errors clustered by city, to the full set of dependent variables. Figure $2 \mathrm{ex}-$ tracts the estimated effect of a Democratic victory for each fitted model. Alongside the findings for police and fire spending, we see a few suggestive (though not statistically significant) tendencies: Democratic mayors spend more, on average, on roads, housing, and administration. They spend less on natural resources, and they have lower police pay and fewer police employees. Democratic mayors appear to rely less on sales taxes, although again, none of these differences nears statistical significance. The null findings for revenue-related measures are consistent with the assessment that revenue decisions are strongly limited by legal constraints (Ladd and Yinger 1989, chap. 6).

\section{Partisan Elections}

We now consider the possibility that partisanship matters only in places where it is especially salient, either because the elections are partisan or because party affiliations appear on the ballot. In these more explicitly partisan elections, voters have easier access to partisan information and elected mayors may feel more accountable to partisan constituents. Forty-one percent of the elections in our data set take place in cities with partisan institutions. Estimating a separate model for these 52 observations, we see an impact of 4.1 percentage points on police spending, with a $95 \%$ confidence interval from 0.87 to 7.4 percentage points. By contrast, when we consider formally nonpartisan elections (but where the mayoral candidates' partisanship is known), we retrieve a result that is nearly zero. The difference between the two 


\section{FIGURE 3 Effect of a Democratic Victory on Police Spending for Varying Window Size}

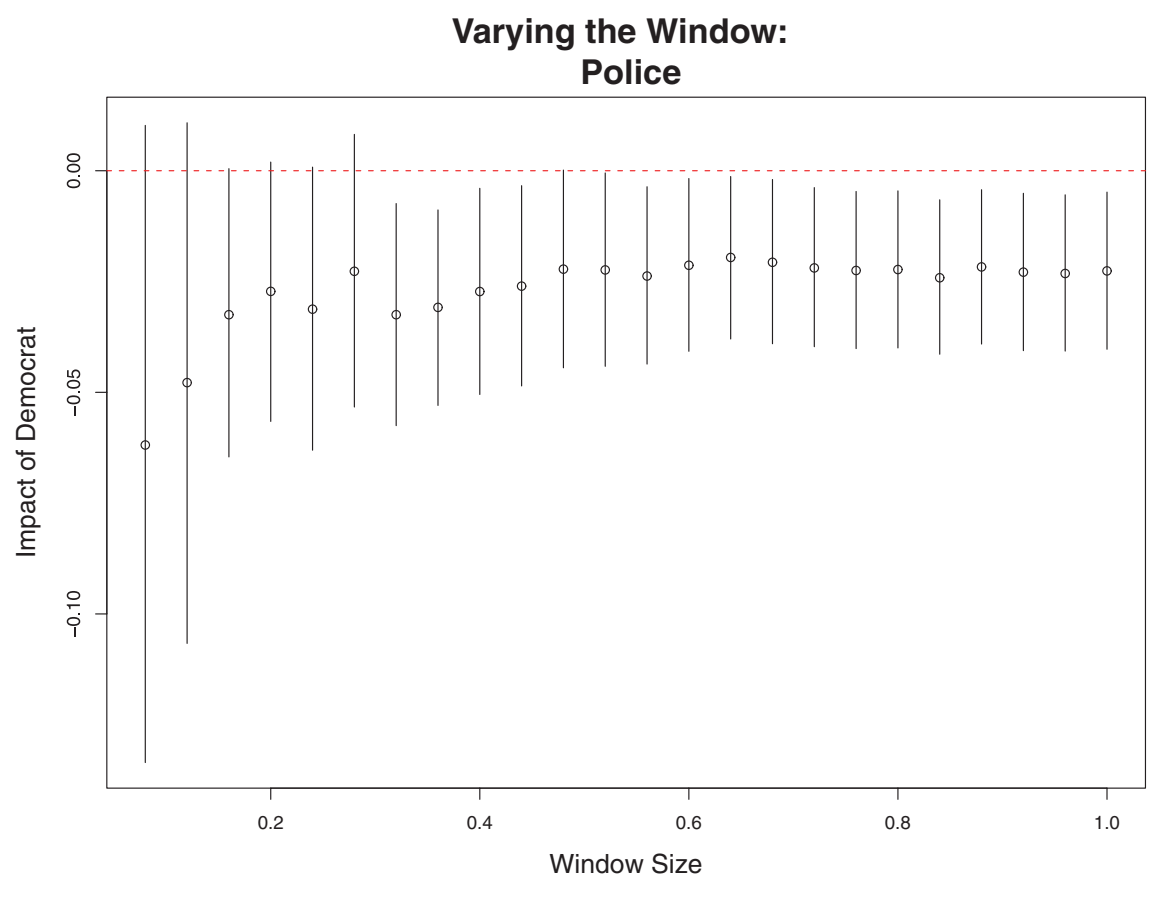

estimates is 4.3 percentage points and is itself statistically significant at the $\mathrm{p}<.10$ level. We also detect a stronger impact of partisanship in the $60 \%$ of cities where party labels appear on the ballot, although the difference with cities that do not provide that information is not as pronounced, and is not statistically significant. The finding that partisanship matters most when it is highly salient also provides a clue about why these results differ from those of Ferriera and Gyourko (2009), whose data set includes many elections where the salience of partisanship is likely to be low. We develop this point at length in the Supplemental Information. The Supplemental Information also demonstrates that other measures of the local and state political environment do not moderate partisanship's local impact.

\section{Robustness}

We now summarize the results of a series of robustness checks which further probe our main findings and help to rule out the possibility that our results are artifacts of any particular empirical approach. Full details of the robustness checks are presented in the Supplemental Information.

- Observations far from the discontinuity: when using RDD, one key robustness check is to vary the distance from the discontinuity within which observations are included in the analysis (Green et al. 2009; Imbens and Lemieux 2007). Doing so reduces the number of observations but also makes the results less model dependent. Figure 3 illustrates the estimated impact of electing a Democratic mayor on police spending as distance from the discontinuity (and thus the number of observations) grows. It shows that the effect is highly robust to the subset of elections considered.

- Multiple imputation: our results are not sensitive to the exclusion of eight observations for which we impute values on a few variables.

- Outliers: our results are not sensitive to the exclusion of any one observation.

- Omitted variables: our results are not sensitive to the inclusion (or exclusion) of dozens of potential covariates that measure demographic characteristics, region, local political institutions, or the partisan environment.

- Time horizon, years, and opponents: as expected, our results are substantively smaller but still statistically significant when we shorten the time horizon from three to two years after the election. The results grow slightly stronger when we only consider elections between a Democrat and a 
Republican. They are not sensitive to limiting our sample to pre-2002 elections, ruling out the possibility of a confounding federal role after September 11, 2001.

\section{Implications and Conclusions}

In 1999, Republican Paul Coble took the mayoralty in Raleigh, North Carolina, after a narrow victory. Its crime rate-7,307 crimes per 100,000 people-was just below the median among cities considered here. During his term in office, Coble increased police spending from $11.1 \%$ of the budget to $14.1 \%$ of the budget two years later. In the same year, Fort Wayne, Indiana, narrowly elected Democrat Graham Richard. In contrast to Raleigh's experience, during Mayor Richard's first term Fort Wayne saw a decline in the share of the budget devoted to the police, from $18.1 \%$ to $14.4 \%$ of the budget over three years. The results above strongly suggest that these changes are not idiosyncratic. When Democrats narrowly win the mayor's chair, spending on policies such as policing-a policy area defined by low levels of overlapping authority-commonly declines relative to total spending. There might not be a Republican way to collect the trash, but there is a Republican way to spend on policing and fire protection.

Party labels are not meaningless in urban politics, but nor do they convey the same information as national party labels. Our findings have important implications for questions of responsiveness and accountability. They demonstrate that local governments are quite constrained in their ability to respond to changing preferences within their cities. When partisans assume political power in a large city, we would expect the newly empowered eliteswho are responsive to different constituencies and who likely hold very different policy preferences than their partisan opponents-to seek major changes in city policy. In most policy areas, however, we do not observe systematic differences in policy outcomes following the narrow victory of a Democratic or Republican mayor, as measured by the share of a city's budget going to that particular spending or revenue category. This stability in spending and revenue patterns is consistent with our explanation that in most policy areas, the structural and political constraints imposed on local government officials largely nullify their ability to enact their preferred policies or respond to the preferences of partisan majorities in the local electorate.

From the perspective of assigning responsibility and holding elected officials accountable for policy outcomes, some observers will find these results disheartening. Even if local government officials want to change policy, it is not at all clear that they have the formal or informal powers needed to make the kinds of changes citizens might want. In a separation of powers system like the United States, assigning responsibility is difficult and complex. When we add the kinds of ambiguity that arise from the overlapping authorities and political constraints facing local officials, the problem of accountability becomes still more acute.

The major exception is in the area of public safety, particularly spending on police and fire protection, where overlapping authority with federal and state actors is relatively low. Here, we find that narrow Republican victories are associated with a substantial and statistically significant increase in the share of city budgets going to these functions. These results are strongest in cities where parties play a formal role in nominating candidates. Under these conditions, the relationship between what decision makers want and the outcomes they produce is much clearer. Holding them accountable for the outcomes they produce is a reasonable goal.

\section{References}

Aldrich, John. 1995. Why Parties? The Origin and Transformation of Political Parties in America. Chicago: University of Chicago Press.

Alesina, Alberto, Reza Baqir, and William Easterly. 1999. "Public Goods and Ethnic Divisions." Quarterly Journal of Economics CXIV(4): 1243-84.

Bailey, Michael A., and Mark Carl Rom. 2004. "A Wider Race? Interstate Competition across Health and Welfare Programs." Journal of Politics 6(2): 326-47.

Barrilleaux, Charles, Thomas Holbrook, and Laura Langer. 2002. "Electoral Competition, Legislative Balance, and American State Welfare Policy." American Journal of Political Science 46(2): 415-27.

Baqir, Reza. 2002. "Districting and Government Overspending." Journal of Political Economy 110(6): 1318-54.

Bartels, Larry. 2008. Unequal Democracy: The Political Economy of the New Gilded Age. Princeton, NJ: Princeton University Press.

Berman, David R. 2003. Local Government and the States: Autonomy, Politics, and Policy. Armonk, NY: M. E. Sharpe.

Briffault, Richard. 1990. "Our Localism, Part I-The Structure of Local Government Law.” Columbia Law Review 90(1): $1-115$.

Brown, Trevor L., and Matthew Potoski. 2003. "Transaction Costs and Institutional Explanations for Government Service Production Decisions." Journal of Public Administration Research and Theory 13(4): 441-68.

Campbell, Angus, Phillip E. Converse, Warren E. Miller, and Donald Stokes. 1960. The American Voter. New York: Wiley.

Caughey, Devin M., and Jasjeet S. Sekhon. 2010. "Regression-Discontinuity Designs and Popular Elections: Implications of Pro-Incumbent Bias in Close U.S. House Races." Available online at http://sekhon.berkeley. edu/papers/CaugheySekhonRD.pdf. 
Clinton, Joshua, Simon Jackman, and Douglas Rivers. 2004. "The Statistical Analysis of Role Call Data." American Political Science Review 98(2): 355-70.

Cook, Thomas D., William R. Shaddish Jr., and Vivian C. Wong. 2005. "Within-Study Comparisons of Experiments and Non-Experiments: What the Findings Imply for the Validity of Different Kinds of Observational Study.” Presented at the French Econometrics Society Meeting on Program Evaluation, Paris.

Craw, Michael. 2006. "Overcoming City Limits: Vertical and Horizontal Models of Local Redistributive Policy Making." Social Science Quarterly 87(2): 361-79.

Eaton, Leslie. 2009. "Belt-Tightening by States Squeezes Cities and Towns." Wall Street Journal, June 20, p. A2.

Edsall, Thomas B. 1991. Chain Reaction: The Impact of Race, Rights, and Taxes on American Politics. New York: Norton.

Erikson, Robert S., Gerald C. Wright, and John P. McIver. 1993. Statehouse Democracy: Public Opinion and Policy in the American States. Cambridge: Cambridge University Press.

Ferreira, Fernando, and Joseph Gyourko. 2009. "Do Political Parties Matter? Evidence from U.S. Cities.” Quarterly Journal of Economics 124(1): 349-97.

Fiorina, Morris, Samuel J. Abrams, and Samuel C. Pope. 2006. Culture War? The Myth of a Polarized America. New York: Pearson Longman.

Fisher, Ronald C. 2003. "The Changing State-Local Fiscal Environment: A 25-Year Retrospective." In State and Local Finances Under Pressure, ed. David L. Sjoquist. Northhampton, MA: Edward Elgar.

Folke, Olle. 2009. "Shades of Brown and Green: Party Effects in Proportional Election Systems." Unpublished manuscript, Columbia University.

Fuchs, Ester R. 1992. Mayors and Money: Fiscal Policy in New York and Chicago. Chicago: University of Chicago Press.

Geller, William A., and Norval Morris. 1992. "Relations between Federal and Local Police." Crime and Justice 15: 231348.

Gerber, Alan S., Daniel P. Kessler, and Marc Meredith. Forthcoming. "The Persuasive Effects of Direct Mail: A Regression Discontinuity Based Approach.” Journal of Politics.

Gerring, John. 1998. Party Ideologies in America, 1928-1996. Cambridge: Cambridge University Press.

Goren, Paul. 2005. "Party Identification and Core Political Values." American Journal of Political Science 49(4): 881-96.

Green, Donald P. 2009. "Regression Adjustments to Experimental Data: Do David Freedman's Concerns Apply to Political Science?" Paper presented at the annual meeting of the Society for Political Methodology, New Haven, CT.

Green, Donald P., Terrence Y. Leong, Holger L. Kern, Alan S. Gerber, and Christopher W. Larimer. 2009. "Testing the Accuracy of Regression Discontinuity Analysis Using Experimental Benchmarks." Political Analysis 17(4): 400-417.

Green, Donald P., Bradley Palmquist, and Eric Schickler. 2002. Partisan Hearts and Minds: Political Parties and the Social Identities of Voters. New Haven, CT: Yale University Press.

Green, Linda V., and Peter J. Kolesar. 2004. "Improving Emergency Responsiveness with Management Science.” Management Science 50(8): 1001-14.
Grodzins, Morton. 2000. "The Federal System." In American Intergovernmental Relations, 3rd ed., ed. Laurence J. O'Toole Jr. Washington, DC: CQ Press, 55-64.

Hacker, Jacob S., and Paul Pierson. 2005. Off Center: The Republican Revolution and the Erosion of American Democracy. New Haven, CT: Yale University Press.

Hahn, Jinyong, Petra Todd, and Wilbert Van DerKlauuw. 2001. "Identification and Estimation of Treatment Effects with a Regression-Discontinuity Design." Econometrica 69(1): 201-9.

Hajnal, Zoltan, and Jessica Trounstine. 2005. "Where Turnout Matters: The Consequences of Uneven Turnout in City Politics." Journal of Politics 67: 515-35.

Hoene, Christopher W., and Michael A. Pagano. 2009. "City Fiscal Conditions in 2009." Research Briefon America's Cities. Washington, DC: National League of Cities.

Hubert, Cynthia. 2008. "Demand for Social Services Rises as Funding Falls.” Sacramento Bee, November 24, p. 10A.

Imbens, Guido W., and Thomas Lemieux. 2007. "Regression Discontinuity Designs: A Guide to Practice." Journal of Econometrics 142: 615-35.

International City/County Management Association (ICMA). 2001. Municipal Form of Government Survey.

Jacobson, Gary C. 1990. The Electoral Origins of Divided Government. Boulder, CO: Westview Press.

Jacoby, William G., and Saundra K. Schneider. 2001. "Variability in State Policy Priorities: An Empirical Analysis." Journal of Politics 63: 544-68.

King, Gary, James Honaker, Anne Joseph, and Kenneth Scheve. 2001. "Analyzing Incomplete Political Science Data: An Alternative Algorithm for Multiple Imputation." American Political Science Review 95(1): 49-69.

Krehbiel, Keith. 1998. Pivotal Politics: A Theory of U.S. Lawmaking. Chicago: University of Chicago Press.

Ladd, Helen F., and John Yinger. 1989. America's Ailing Cities: Fiscal Health and the Design of Urban Policy. Baltimore: Johns Hopkins University Press.

Lee, David S., Enrico Moretti, and Matthew J. Butler. 2004. "Do Voters Affect or Elect Policies? Evidence from the U.S. House." Quarterly Journal of Economics 119: 807-59.

Leigh, Andrew. 2007. "Estimating the Impact of Gubernatorial Partisanship on Policy Settings and Economic Outcomes: A Regression Discontinuity Approach." European Journal of Political Economy 24: 256-68.

McCarty, Nolan M., Keith T. Poole, and Howard Rosenthal. 2006. Polarized America: The Dance of Ideology and Unequal Riches. Cambridge, MA: MIT Press.

Meredith, Marc. 2009. "Persistence in Political Participation." Quarterly Journal of Political Science 4(3): 186-208.

Methe, David T., and James L. Perry. 1980. “The Impacts of Collective Bargaining on Local Government Services: A Review of Research." Public Administration Review 40: 359-71.

Morgan, David R., and Sheliah S. Watson. 1995. "The Effects of Mayoral Power on Urban Fiscal Policy.” Policy Studies Journal 23(2): 231-43.

Mullainathan, Sendhil, and Ebonya Washington. 2009. "Sticking with Your Vote: Cognitive Dissonance and Voting." American Economics Journal: Applied Economics 1: 86-111. 
Mullins, Daniel R. 2003. "Popular Processes and the Transformation of State and Local Government Finance." In State and Local Finances under Pressure. Ed. David L. Sjoquist. Northhampton, MA: Edward Elgar.

Niemi, Richard G., Stephen Wright, and Lynda W. Powell. 1987. "Multiple Party Identifiers and the Measurement of Party Identification." Journal of Politics 49: 1093-1103.

Nivola, Pietro. 2002. Tense Commandments: Federal Prescriptions and City Problems. Washington, DC: Brookings Institution Press.

Pagano, Michael A., and Christopher W. Hoene. 2008. "City Fiscal Conditions in 2008." Research Briefon America's Cities. Washington, DC: National League of Cities.

Peterson, Paul E. 1981. City Limits. Chicago: University of Chicago Press.

Peterson, Paul E. 1995. The Price of Federalism. Washington, DC: Brookings Institution Press.

Petrocik, John R. 1996. "Issue Ownership in Presidential Elections, with a 1980 Case Study." American Journal of Political Science 40(3): 825-50.

Poole, Keith T., and Howard Rosenthal. 1997. Congress: A Political-Economic History of Roll Call Voting. New York: Oxford University Press.

Popkin, Samuel. 1994. The Reasoning Voter: Communication and Persuasion in Presidential Campaigns. Chicago: University of Chicago Press.

Rae, Douglas. 2003. City: Urbanism and Its End. New Haven, CT: Yale University Press.

Richman, Daniel. 2006. "The Past, Present and Future of Violent Crime Federalism." Crime and Justice 34: 377-439.

Roth, Jeffrey A., and Joseph F. Ryan. 2000. The COPS Program After 4 Years-National Evaluation. National Institute of Justice, Research In Brief, Washington, DC.

Ruhil, Anirudh. 2003. "Structural Change and Fiscal Flows: A Framework for Analyzing the Effects of Urban Events." Urban Affairs Review 38(3): 396-416.

Schafer, Joseph L. 1997. Analysis of Incomplete Multivariate Data. London: Chapman \& Hall.

Schaffner, Brian F., Matthew Streb, and Gerald Wright. 2001. "Teams without Uniforms: The Nonpartisan Ballot in State and Local Elections." Political Research Quarterly 54(1): 7-30.

Schleicher, David. 2007. "Why Is There No Partisan Competition in City Council Elections? The Role of Election Law." Journal of Law and Politics 23: 419-74.

Self, Robert O. 2003. American Babylon: Race and the Struggle for Postwar Oakland. Princeton, NJ: Princeton University Press.

Tiebout, Charles. 1956. “A Pure Theory of Local Expenditures.” Journal of Political Economy 64(October): 416-24.

Trounstine, Jessica. Forthcoming. "Evidence of a Local Incumbency Advantage." Legislative Studies Quarterly.

Wallin, Bruce A. 2004. "The Tax Revolt in Massachusetts.” Public Budgeting and Finance (Winter): 34-50.
Warren, Patrick. 2009. "State Parties and Taxes: A Comment on Reed in the Context of Close Legislatures." Available at SSRN: http: //ssrn.com/abstract $=1144057$.

Welch, Susan. 1990. "The Impact of At-Large Elections on the Representation of Blacks and Hispanics." Journal of Politics 52(4): 1050-76.

Wolman, Harold, John Strate, and Alan Melchior. 1996. "Does Changing Mayors Matter? Journal of Politics 58(1): 201-23.

Wooldridge, Jeffrey M. 2003. "Cluster-Sample Methods in Applied Econometrics.” American Economic Review 93(2): 133-38.

Wright, Gerald C., and Brian F. Schaffner. 2002. "The Influence of Party: Evidence from the State Legislatures." American Political Science Review 96: 367-79.

\section{Supporting Information}

Additional Supporting Information may be found in the online version of this article:

Table 1: Descriptive Statistics, Independent Variables, 134 City Elections

Table 2: Descriptive Statistics, Dependent Variables, 134 City Elections

Table 3: OLS Estimates, DV = Changes in the Share of Spending on Fire, 134 City Elections

Table 4: Full List of City Elections

Figure 1: OLS Estimates, Effect of a Democratic Victory on Police Spending. Conditional on the inclusion of potential confounding variables.

Figure 2: OLS Estimates, Placebo Tests, DV = Covariates, IV $=$ Democratic Victory

Figure 3: OLS Estimates, Comparisons with Ferriera and Gyourko (2009)'s data set. The dependent variable is the change in the three-year share of expenditures on the police. The models include only the percent Democratic, an indictor for a Democratic victory, and various functions of those variables.

Please note: Wiley-Blackwell are not responsible for the content or functionality of any supporting materials supplied by the authors. Any queries (other than missing material) should be directed to the corresponding author for the article. 